\title{
The Influence of the Negative Campaign on Facebook: The Role of Political Actors and Citizens in the Use of Criticism and Political Attack in the 2016 Spanish General Elections
}

\author{
Silvia Marcos-García *(D), Laura Alonso-Muñoz and Andreu Casero-Ripollés \\ Department of Communication Sciences, Faculty of Humanities and Social Sciences, Universitat Jaume I de \\ Castelló, Av. Vicent Sos Baynat, s/n, 12071 Castellón de la Plana, Spain; lalonso@uji.es (L.A.-M.); \\ casero@uji.es (A.C.-R.) \\ * Correspondence: smarcos@uji.es
}

\section{check for}

updates

Citation: Marcos-García, Silvia, Laura Alonso-Muñoz, and Andreu Casero-Ripollés. 2021. The Influence of the Negative Campaign on Facebook: The Role of Political Actors and Citizens in the Use of Criticism and Political Attack in the 2016 Spanish General Elections. Social Sciences 10: 356. https://doi.org/ 10.3390/socsci10100356

Academic Editor: Nigel Parton

Received: 31 August 2021

Accepted: 22 September 2021

Published: 26 September 2021

Publisher's Note: MDPI stays neutral with regard to jurisdictional claims in published maps and institutional affiliations.

Copyright: (c) 2021 by the authors. Licensee MDPI, Basel, Switzerland. This article is an open access article distributed under the terms and conditions of the Creative Commons Attribution (CC BY) license (https:// creativecommons.org/licenses/by/ $4.0 /)$.

\begin{abstract}
Social media has become an essential platform in the field of digital political communication In the context of accommodating electoral campaigns to digital media and the absence of barriers to freedom of expression existing on these platforms, attacks on political rivals and negative campaigns are increasing on social media. This research analyzes the use of criticism on Facebook by political actors during the electoral campaign and citizens' reactions to these messages. The sample $(n=601)$ contains the publications disseminated on Facebook by political parties and leaders during the electoral campaign of the general elections of 26 June 2016 in Spain. The results show that criticism is an emerging resource in the digital communication strategy of political actors, mainly used by the opposition parties and their candidates, who focus their attacks on the party and leader of the Government. Attacks are mainly focused on the professional side of their rivals, although they also give a central role to emotions. Citizens are attracted to these attacks and are prone to interact with posts that include this resource.
\end{abstract}

Keywords: negative campaign; criticism; Facebook; Spain; electoral campaign; political communication

\section{Introduction}

In the recent decades, technological advances have transformed electoral campaigns. Both political parties and leaders have adapted their communication strategies to digital media (Stromer-Galley 2014). In this context, some dynamics representative of the offline environment, such as the negative campaigns and criticism of political adversaries, have been gaining prominence in the digital environment (Greer and LaPointe 2004; Klotz 2004). Among other factors, this is promoted by the absence of barriers to freedom of expression on these digital platforms (Shirky 2011).

The disintermediation offered by social media enables political actors not only to disseminate their information but also to take advantage of this space to criticize their adversaries and highlight their defects, errors, and contradictions (Maier and Nai 2021; Stevens 2012; Lau and Pomper 2004). This type of message, linked to negative emotions, generates a larger impact on the audience, who more easily remembers these contents in comparison to those presented from a positive perspective (D'Adamo and Beaudox 2016). Thus, emotions such as fear or frustration are perceived more quickly and cause a greater impression among users (Castells 2012). However, according to some authors (Berganza-Conde 2008; Patterson 1993), the use of the negative campaign by political actors involves risks, such as disaffection or political polarization.

In recent years, social media has become a territory where reproaches, attacks, and even hate speech have increased. Despite the growing importance of using criticism in digital political communication, there are still few studies that analyze how negative 
campaigns are carried out on these platforms. Therefore, we still know little about the characteristics of this phenomenon in the digital environment.

Therefore, it seems necessary to provide new evidence on the dynamics that political actors employ to activate negative campaigns in the digital environment, and on the users' reaction to these communication strategies. When it comes to exposing political criticism on social media, Facebook is positioned as the preferred platform for four reasons. The first reason is its unrestricted nature in the construction of the messages. Compared to platforms such as Twitter that limit the number of characters in posts to 240, Facebook offers an open space where political actors can develop their arguments, including criticism and attacks on rivals. Second, it is widely popular both at the user level and in the presence of political parties and leaders. With 1.5 billion users, Facebook is the digital platform most used by citizens worldwide. This makes this social media an attractive space for political actors, who seek to expand the radius of circulation of their messages, including negative ones. Third, because of the multiple forms of interaction. In addition to the "like" button, Facebook enables users to react to messages with varied emotions such as love, laugh, or anger, among others. A potential that is not present in other platforms and which connects with the relevance of emotions in the digital environment. Finally, the fourth reason is the lack of studies on the negative campaigns on Facebook. So far, this dynamic has been studied in environments such as websites (Valera-Ordaz and López-García 2014) or on Twitter (Ceron and d'Adda 2016), but not on Facebook.

To provide new evidence of the use of Facebook in the communication strategy of political actors, this study examines the role of criticism and attacks on rivals in the communication dynamics of the main Spanish political parties and their leaders on Facebook during the 2016 Spanish general elections. This research aims to know the degree and type of criticism exploited by these actors on their Facebook profiles, and to analyze the reactions of users to this type of message.

\section{Theoretical Framework}

\subsection{Negativity in the Electoral Campaign: From Television to Social Media}

The emergence of television as a medium of reference for political communication during the 1950s implied a strong change in the strategies used during electoral campaigns, largely specific to marketing, whose objective was to achieve maximum effectiveness (Maarek 2009). Images, much easier for the human mind to recognize and remember (Vogt and Magnussen 2007), together with the introduction of emotions and personal aspects in electoral campaigns, gave way to new practices and styles in the communication strategy of political parties and candidates (Vergeer et al. 2013). One of the dynamics that became most popular in this period is the negative campaign, understood in general terms as "any act consisting of attacking or criticizing the opponent" (Geer 2006, p. 23).

One of the most relevant examples is the presidential campaign of Adlai Stevenson in the United States in 1956. The team of Adlai Stevenson, a Democratic candidate, broadcasted some spots starring the Republican candidate Dwight D. Eisenhower to highlight his unfulfilled political promises and to discredit him in front of his voters (García Beaudoux 2014). Another example of a negative campaign was produced years later and is known as "Daisy Spot" or "Peace, little girl". This famous spot was created by the team of the Democratic candidate Lyndon Johnson in the campaign for the 1964 US presidential election. The advert showed a girl defoliating a daisy flower while a voice-over counted down until a large nuclear explosion appeared on the screen. Despite the fact that it only aired once, the announcement generated much controversy, reinforcing the warmongering and pro-nuclear perception of Barry Goldwater, the Republican candidate (Mann 2011). After this controversy, Lyndon Johnson won the elections. This fact demonstrated that using negative emotions in electoral spots had a greater capacity to mobilize the electorate (García Beaudoux and D'Adamo 2013). 
Far from being a one-off phenomenon, the negative campaign has become a growing resource in Western democracies (Schweitzer 2010). In the last decade, the consolidation of social media has favored its growth, thanks, among other factors, to the facilities for freedom of expression that these platforms offer. As happened on television, political actors use these digital media as a vehicle to highlight and amplify the adversary's past or present defects, errors, and contradictions, rather than highlighting their virtues ( $\mathrm{D}^{\prime}$ Adamo and Beaudox 2016; Ceron and d'Adda 2016; Valera-Ordaz and López-García 2014). In addition to criticizing the program, ideology, or trajectory of the opponent, there are other attacks based on arguments, both true and false, about his or her character or personal traits (Maier and Nai 2021; Stevens 2012; Lau and Pomper 2004). Therefore, the ideology and political trajectory of political parties and leaders have become significant features in how these actors use criticism in the digital environment. On the one hand, parties and candidates ideologically located at the extremes criticize those who position themselves in the center with greater frequency and intensity (Nai and Sciarini 2018; Lau and Pomper 2004). On the other hand, emerging parties and candidates, whose political trajectory is shorter, are the ones that most base their strategy on the negative campaign, focusing their messages on criticizing their opponents rather than highlighting their achievements. These are scarce as they are new actors on the political scene. On the contrary, the formations and leaders with the longest trajectory tend to propose positive campaigns, highlighting the achievements made throughout their mandates (Valli and Nai 2020). On the other hand, Abejón-Mendoza and Mayoral-Sánchez (2017) point out that, in the Spanish case, the opposite occurs. While traditional parties promote a strategy based on fear, emerging parties focus their messages on generating enthusiasm for political change.

Although criticism and confrontation are inherent to politics (Mazzoleni 2010), cyber campaigns have standardized this type of practice (Greer and LaPointe 2004; Klotz 2004). In addition, the democratization of the communicative space implied by social media has meant that criticism also spreads and can be exercised by new actors, whose role was secondary and residual in previous times (Castells 2009). This dynamic has potentially negative effects because it encourages political disaffection (Patterson 1993) and the appearance of new populist political actors who focus their communication strategy more on negativity than on the formulation of programmatic proposals (Enli 2017). Although some studies (Alonso-Muñoz and Casero-Ripollés 2018; López-Meri et al. 2017) have warned of the weight that criticism has reached during electoral campaign periods, it is still unknown how politicians articulate this type of message on social media. Thus, based on the previous literature, the following research questions are posed:

RQ1: What is the use that political actors make of criticism and who are they targeting on Facebook?

RQ2: What kind of criticism do political actors raise on Facebook?

\subsection{The Impact of Criticism on Facebook Users}

Social media has become a new space for the expression and transmission of ideas (Mathieu 2015), as well as new means to deliberate on the main political problems that affect society (Bennett 2012; Dahlberg 2007). A role that in previous decades had been occupied by the media, especially television (Cammaerts et al. 2013). This fact explains the growing number of users who use the Internet and social media and the interest of politicians and parties to use them, especially during electoral campaign periods (AlonsoMuñoz et al. 2021; Chaves-Montero et al. 2017; Elmer 2013). Digital technologies have become a space for free expression where any user can openly participate (Benkler 2007). In this sense, social media act as a loudspeaker for public opinion, which arises to challenge public powers and demand accountability to society (Alonso-Muñoz and Casero-Ripollés 2017). The speed, immediacy, and viralization capacity make social media a powerful tool for citizens to express their opinions, supervise the political class, and criticize it for its way of acting (Marcos-García et al. 2017). In addition, aspects such as anonymity or the use of pseudonyms make it possible to increase criticism because it is very difficult to find those 
who post these kinds of messages. This impunity encourages others to do the same (Cabo Isasi and Juanatey 2016).

Some studies (Jungherr 2016; Dang-Xuan et al. 2013) maintain that negative comments predominate mainly on social media. Research such as that of Marcos-García et al. (2017) show that citizens use social media as a channel to manifest their criticism and dissatisfaction with politics, mainly using humor or parody. Likewise, other studies show how users increase their interaction in posts where political actors, especially those in the opposition, criticize or attack their adversaries (Ballesteros-Herencia and Gómez-García 2020; Marcos-García et al. 2020). Therefore, negative information produces more impact among users, being perceived more quickly, causing a greater impression, and being remembered more easily than positive information (D'Adamo and Beaudox 2016). In other words, the use of negative emotions activates citizens' attention to a greater extent (García Beaudoux and D'Adamo 2013), especially frustration or fear, which have a paralyzing effect (Castells 2012). In environments such as Facebook, emotions take on special relevance thanks to the multiple forms of interaction that the user has (Fenoll and Cano-Orón 2017; Haro-deRosario et al. 2016). Since 2016, this social media has expanded the emotional response to a message. In addition to the usual "like" reaction, users can show other emotions such as love, laugh (haha), surprise (wow), sadness, or anger (Coromina et al. 2018).

Taking these arguments into account, we pose the following research question:

RQ3: How do Facebook users react to criticism issued by Spanish political actors?

\section{Materials and Methods}

\subsection{Sample}

The methodology is based on quantitative content analysis. The sample of this research focuses on the electoral campaign of the Spanish general elections held on 26 June 2016. In particular, the 15 official days of the campaign, the day before the election, the election day, and the day after the election day were studied. During this period, the Facebook posts and messages by the Popular Party (PP), the Socialist Party (PSOE), Podemos, Ciudadanos (C's), and Izquierda Unida (IU) were analyzed. Moreover, we analyzed the messages posted by their respective candidates: Mariano Rajoy, Pedro Sánchez, Pablo Iglesias, Albert Rivera, and Alberto Garzón. It should be noted that, although Podemos and IU participated in these elections under the Unidos Podemos coalition, both parties and their respective leaders maintained a differentiated activity on their Facebook accounts, carrying out independent communication strategies. The total sample comprises 601 Facebook messages (Table 1).

Table 1. Distribution of the Analysis Sample.

\begin{tabular}{crc}
\hline & Political Actor & $\begin{array}{c}\text { Number of Messages on } \\
\text { Facebook }\end{array}$ \\
\hline Parties & Partido Popular (PP) & 76 \\
& Partido Socialista (PSOE) & 93 \\
& Podemos & 50 \\
& Ciudadanos (Cs) & 59 \\
Candidates & Izquierda Unida (IU) & 95 \\
& Mariano Rajoy & 38 \\
& Pedro Sánchez & 55 \\
& Pablo Iglesias & 33 \\
Albert Rivera & 14 \\
& Alberto Garzón & 88 \\
& Total & 601 \\
\hline
\end{tabular}

The Spanish elections held in June 2016 were historic. Previously, on 20 December 2015, two new political parties had emerged in the elections: Podemos, on the left, and Ciudadanos, on the center-right. This meant the end of bipartisanship, embodied by the Partido Socialista (PSOE) and Partido Popular (PP), which dominated the Spanish political system for more than 40 years (Barberà et al. 2019; Orriols and Cordero 2016). The outcome 
of the 2015 elections was a very fragmented Parliament, where no political force had a majority, and political factions were required to compromise. After months of negotiations, the investiture of the socialist candidate, Pedro Sánchez, failed as he failed to obtain the necessary support to become president of the Government. As a result, Parliament was dissolved in May and new elections were called on 26 June 2016. The irruption of new political actors generates new alternative discursive strategies to the traditional bipartisanship. Therefore, the 2016 Spanish general elections are a relevant case study for two reasons. Firstly, these elections are the first in which traditional and emerging parties have options to govern. Secondly, the appearance of new political discourses enables the development of new communication strategies in the digital environment.

The choice of Facebook is due to the popularity of this social media among users. According to data from the Digital Report (2021), Facebook has 1.5 billion users in 2021, being the platform with the largest audience worldwide. Likewise, it is also a preferred social media platform within the communication strategies of political actors. In 2020, there were 1089 personal and institutional Facebook accounts of presidents and ministers of the member countries of the United Nations Organization (Twiplomacy 2020). In addition to its high audience, political actors open a Facebook profile because it turns out to be a versatile campaign tool in which they can inform their followers of their electoral program, interact with their followers, and mobilize them to go to vote (Alonso-Muñoz et al. 2021; López-Meri et al. 2020).

\subsection{Measures and Procedure}

The sample was segmented according to three parameters. First, the axis of political trajectory: PP, PSOE, and IU are three of the parties with the longest history in the Spanish political system, while Podemos and C's are two emerging parties. Second, the ideological axis: PP and C's and their respective leaders are situated as right-wing political actors, while PSOE, Podemos, and IU are left-wing political actors. Third, the axis of the government's position. During the period of this investigation, PP and its leader, Mariano Rajoy, held the presidency of the Government, while PSOE, Podemos, C's, and IU were the parties in the opposition.

This article seeks to analyze the presence of criticism in the communicative strategy of the political actors on Facebook. To this end, it proposes a new analysis model composed of 6 variables and 20 categories. In the case of variables relating to typology and basis of the attack, this model adapts the proposal of García Beaudoux and D'Adamo (2013) for the study of the negative campaign. To carry out the analysis, a list of indicators adapted to the object of study of this research has been prepared. Table 2 shows the analysis proposal used, in which six variables with twenty categories were defined for the study of criticism in the electoral campaign on Facebook.

Table 2. Analysis Proposal.

\begin{tabular}{cc}
\hline Yes & Use of Criticism \\
\hline No & $\begin{array}{c}\text { The publication contains a critique or attack. } \\
\text { The publication does not contain a critique or attack. }\end{array}$ \\
\hline $\begin{array}{c}\text { Political Party } \\
\text { Male or FemalePolitician } \\
\text { Media or journalist } \\
\begin{array}{c}\text { Institution or publicorganization } \\
\text { Entrepreneur orcompany } \\
\text { Others }\end{array}\end{array}$ & $\begin{array}{c}\text { Criticism is directed at a certain political party. } \\
\text { Criticism is directed at a certain politician. }\end{array}$ \\
$\begin{array}{c}\text { Criticism is directed at a specific media, program, or journalist. } \\
\text { Criticism is directed at a specific institution or public organization. } \\
\text { Criticism is directed at a specific businessman or company. } \\
\text { Criticism is directed at another actor, not mentioned in the previous } \\
\text { categories. }\end{array}$ \\
\hline
\end{tabular}


Table 2. Cont.

\begin{tabular}{|c|c|}
\hline \multicolumn{2}{|c|}{ Typology of the Attack } \\
\hline Personal & $\begin{array}{c}\text { Criticism or attack is directed at the personal traits or qualities of a } \\
\text { certain actor. }\end{array}$ \\
\hline Trajectory & $\begin{array}{l}\text { Criticism or attack is directed at the functions or positions previously } \\
\text { held by a certain actor. }\end{array}$ \\
\hline Political & $\begin{array}{c}\text { Criticism or attack is directed at the proposals or positions of a certain } \\
\text { actor regarding a topic or question. }\end{array}$ \\
\hline Ideological & Criticism or attack focuses on the ideology and values of a certain actor. \\
\hline \multicolumn{2}{|c|}{ Intensity of the Attack } \\
\hline $\begin{array}{c}\text { Direct } \\
\text { Collateral }\end{array}$ & $\begin{array}{c}\text { Messages in which a certain actor is directly criticized. } \\
\text { Messages where a certain actor is criticized while the attack remains in } \\
\text { the background. Therefore, the main function of the message is not to } \\
\text { criticize. }\end{array}$ \\
\hline \multicolumn{2}{|c|}{ Structure of the Attack } \\
\hline $\begin{array}{c}\text { Simple } \\
\text { Comparative }\end{array}$ & $\begin{array}{l}\text { Messages in which only a certain actor is criticized. } \\
\text { Messages in which a certain actor is criticized while emphasizing and } \\
\text { highlighting positive aspects or merits of oneself. }\end{array}$ \\
\hline \multicolumn{2}{|c|}{ Reason of the Attack } \\
\hline Based on data & $\begin{array}{l}\text { The criticism or attack is based on data or information, as well as on the } \\
\text { statements that the attacked actor has previously made. }\end{array}$ \\
\hline Emotional & $\begin{array}{l}\text { The criticism or attack is based on language that evokes negative } \\
\text { emotions or feelings such as fear, outrage, anger, or disappointment. }\end{array}$ \\
\hline Ethical & $\begin{array}{c}\text { Criticisms or attacks question the credibility of a proposal or action } \\
\text { carried out by a certain actor. }\end{array}$ \\
\hline Humorous & $\begin{array}{l}\text { The criticism or attack is made from a humorous perspective, to } \\
\text { ridicule one or more actors. }\end{array}$ \\
\hline
\end{tabular}

The sample data was extracted with the Netvizz application. The analysis was carried out by two coders. The intercoder reliability was calculated with Scott's Pi formula, reaching a level of 0.97 . The statistical treatment of the results was done with the SPSS program (v.24) (Powered by IBM, Armonk, NY, USA).

\section{Results}

\subsection{Level of Use and Recipients of Criticism by Political Actors on Facebook}

Responding to RQ1, criticism became an emerging mechanism in the communication strategies proposed by political actors on Facebook (Figure 1). A total of 23\% of the messages published by these actors contain some criticism or attack. It is relevant as there are no significant differences in the general use of this resource by both political parties and their candidates. While the former includes criticism in $24.1 \%$ of their messages, the latter uses this resource in $18 \%$ of their publications.

The results reveal two significant trends regarding the use of criticism by political actors, which show that the position of parties and leaders in government and their ideology are determining factors. First, it is observed that the use of criticism is directly conditioned by the axis of the government's position. This way, the opposition parties, that is, PSOE, IU, Podemos, and C's, and their respective leaders, incorporate a greater number of strikes in their messages. On the contrary, PP and Mariano Rajoy, as a party and leader in the Government, hardly use this resource. In the latter case, while the PP only uses it in $9.20 \%$ of its messages, Rajoy does not use the attack as part of his communication strategy (Figure 1). Concerning this first trend, it is also worth noting how the political groups in the opposition and their candidates coincide in assigning most of their attacks to the Government, represented by the Popular Party and Mariano Rajoy. IU (63.89\%), Pablo Iglesias (50\%), and Alberto Garzón (50\%) direct half or more of their criticism toward the Popular Party. 


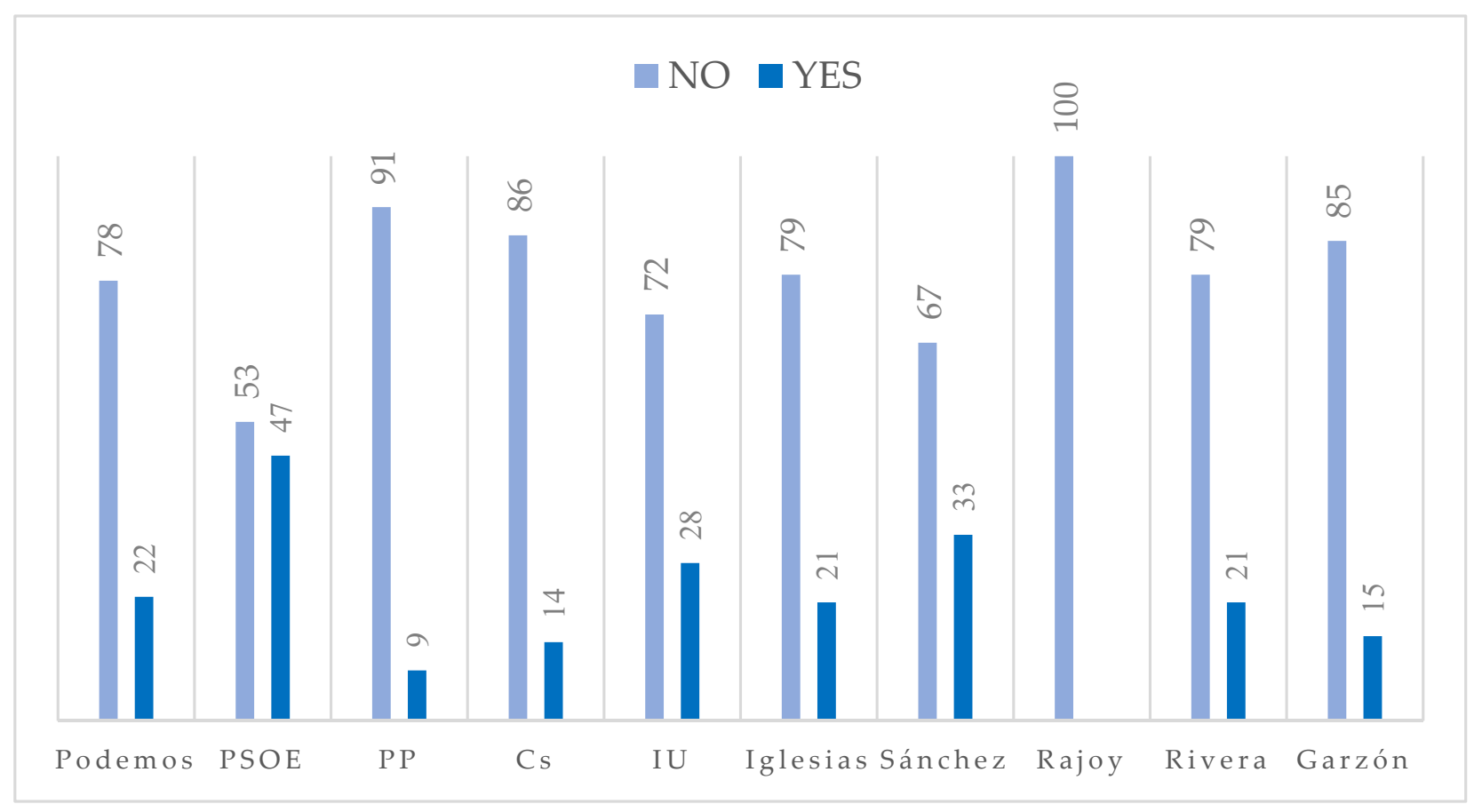

Figure 1. Presence of Criticism in the Facebook Posts of Political Actors (\%).

In parallel, PSOE and its candidate, Pedro Sánchez, prioritize a dynamic based on negative personalization. In this sense, both profiles put the criticisms directed at Mariano Rajoy before the Popular Party. Therefore, they place the candidate at the center of their accusations to weaken his figure and political proposals (Table 3). This practice is repeated with Pablo Iglesias, the second actor most criticized by the Socialist Party and its leader. In this case, the attacks directed at Iglesias are conditioned by the ideological position of these actors. As representatives of the left, they fight for the same voters. For this reason, the use of attacks is conveyed to differentiate themselves from rivals.

Table 3. Recipients of Criticism on Facebook (\%).

\begin{tabular}{|c|c|c|c|c|c|c|c|c|c|c|}
\hline & PP & PSOE & Podemos & IU & C's & Rajoy & Sánchez & Iglesias & Garzón & Rivera \\
\hline PSOE & 14.29 & - & 7.69 & 8.33 & 27.27 & - & - & 30 & - & 20 \\
\hline PP & - & 13.75 & 38.46 & 63.89 & 36.36 & - & 20 & 50 & 50 & 20 \\
\hline$C^{\prime} s$ & - & - & - & 8.33 & - & - & - & - & - & - \\
\hline Podemos & 14.29 & 10 & - & - & 18.18 & - & 8.57 & - & - & 20 \\
\hline Other political parties & - & 6.25 & - & 2.78 & 18.18 & - & 8.57 & - & 7.14 & 20 \\
\hline Sánchez & - & - & 7.69 & - & - & - & - & - & - & - \\
\hline Rajoy & - & 36.25 & 7.69 & - & - & - & 31.43 & - & 7.14 & - \\
\hline Rivera & - & - & - & - & - & - & - & - & - & - \\
\hline Iglesias & 42.86 & 27.50 & - & - & - & - & 28.57 & - & - & - \\
\hline Other politicians & - & 6.25 & 15.38 & 8.33 & - & - & 2.86 & - & 14.29 & - \\
\hline Media/Journalists & - & - & - & - & - & - & - & - & - & - \\
\hline Public organizations & - & - & 7.69 & 2.78 & - & - & - & 10 & 21.43 & - \\
\hline Entrepreneur/Company & - & - & - & 2.78 & - & - & - & - & - & - \\
\hline Other actors & 28.57 & - & 15.38 & 2.78 & - & - & - & 10 & - & 20 \\
\hline TOTAL & 100 & 100 & 100 & 100 & 100 & - & 100 & 100 & 100 & 100 \\
\hline
\end{tabular}


The second trend reveals that the ideological dimension is decisive in the level of the use of criticism, especially in the case of left-wing political parties such as PSOE (47.3\%), IU $(28.4 \%)$, and Podemos (22\%). However, right-wing parties like C's (13.6\%) and PP (9.2\%) make a smaller use of criticism. In the case of the candidates, the ideological factor is less decisive since all of them include attacks in their messages, except for Mariano Rajoy, who does not use this resource. Pedro Sánchez is the leader who criticizes the most (32.7\%), followed by Pablo Iglesias (21.2\%), Albert Rivera (21.4\%), and Alberto Garzón (14.8\%) (Figure 1).

\subsection{Typology of Criticism Issued by Political Actors on Facebook}

Concerning RQ2 on the type of criticism used by political actors on Facebook, the data reveal that the collective-individual dimension is a determining factor. While political parties tend to prioritize the use of attacks on the professional role of their rivals, candidates tend to focus their criticism on the values and ideology of their opponents. Specifically, the type of criticism most exploited by the parties is about the trajectory of their political rivals $(46.38 \%)$, that is, messages where they attack and discredit the functions and decisions made by their opponents, as well as their current or previous position within the political system. C's (62.5\%), IU (55.56\%), and PSOE (52.27\%) are the formations that prioritize this strategy the most over other types of attacks. Only the candidates Alberto Garzón (61.64\%) and Pedro Sánchez (55.56\%) coincide with their respective parties and make considerable use of criticism centered on the trajectory of their political rivals (Figure 2).

Complementarily, the second type of criticism most used by the parties is the political attack $(24.64 \%)$. This focuses on criticizing the measures and proposals that opponents present in their electoral program. Although the PP $(57.14 \%)$ is the only profile that prioritizes political attack over other types of criticism, IU (33.33\%), Podemos (27.27\%), PSOE (25\%), and C's (25\%) also use it in a considerable part of their publications.

Concerning leaders' strategy, criticisms directed at the values and ideological positioning of their rivals are the most predominant. The use of ideological attacks stands out especially in the publications of Albert Rivera (100\%) and Pablo Iglesias (42.86\%). It should be noted that Iglesias is the only one who coincides with his party, which also prioritizes this type of attack when addressing rivals (45.45\%) (Figure 2). As representatives of emerging parties, these leaders use this type of criticism to assimilate traditional parties, such as PP or PSOE, with the elite and the establishment. Meanwhile, this type of criticism is indirectly linked to requests for political and democratic renewal. In other words, its use is based on criticizing the position of power of the traditional parties in the Spanish political system and focuses on the need for political change and democratic renewal.

At the same time, there is a growing use of personal attacks. This dynamic is used especially by PSOE (22.73\%) and Pedro Sánchez (27.78\%). Next are Podemos (18.18\%) and Pablo Iglesias (14.29\%), as representatives of the left, and the Popular Party (14.29\%) in the right wing (Figure 2). These parties and leaders coincide in articulating part of their communication strategy around the attributes, traits, and other personal aspects of their rivals. Thus, when these profiles use criticism, their political discourse is reduced to a confrontation between personalities. On the contrary, they do not delve into other purely political questions such as, for example, whether or not their opponents fulfill their functions as politicians. This communicative strategy is directly related to the phenomenon of political personalization, where political actors tend to criticize leaders more than parties.

If we focus on how political actors carry out their criticisms, the data reveals three significant strategies. First, regardless of ideology or trajectory, parties and leaders tend to use criticism collaterally $(63.32 \%)$ so that the main function of their messages is not a direct strike on their rivals. In other words, while political actors talk about other issues in their publications, they take advantage of these messages to implicitly criticize other parties, rivals, events, or ideas. 


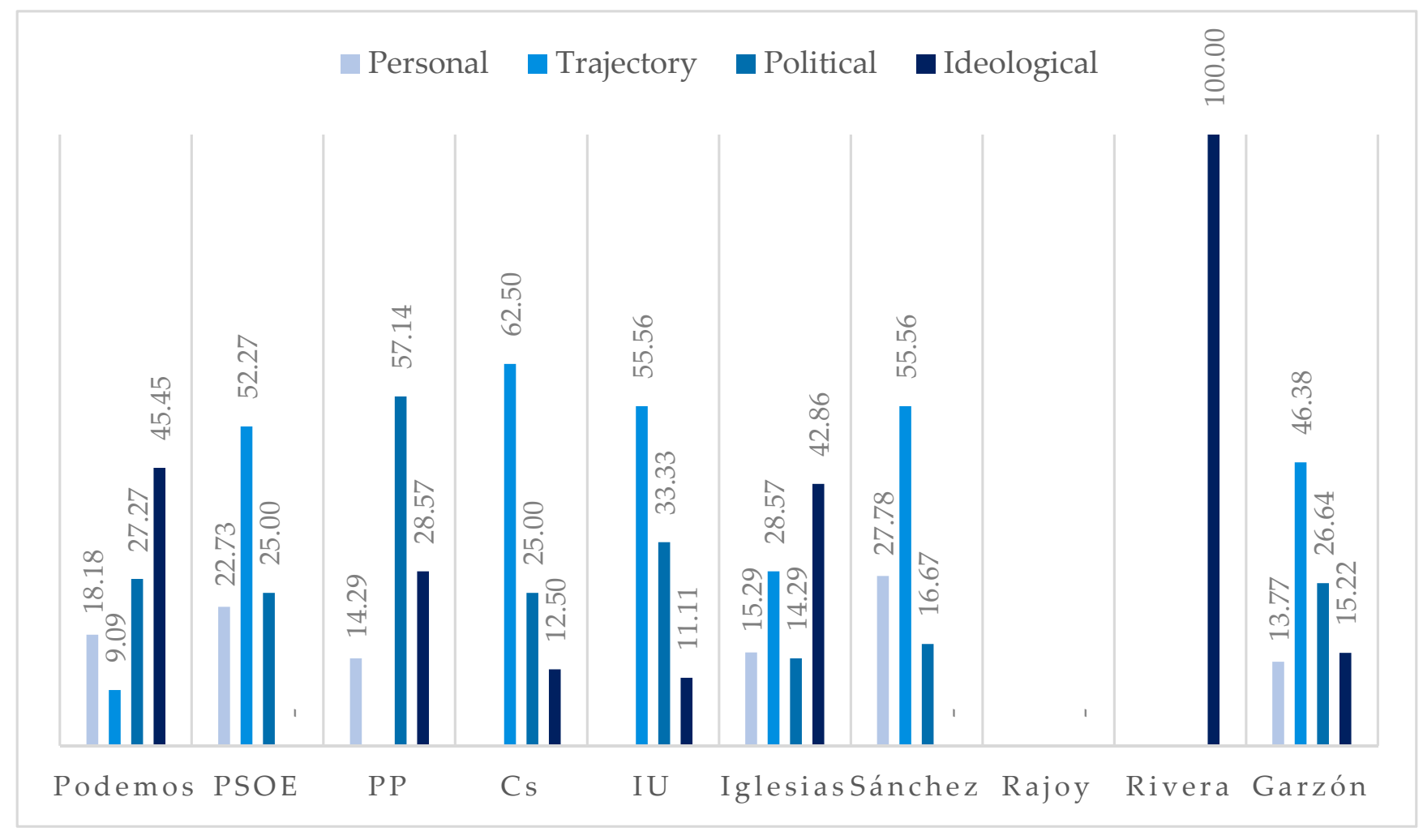

Figure 2. Type of Criticism Used by Political Actors on Facebook (\%).

This dynamic is complemented by the second strategy used by political actors when they use criticism in their posts. The results show that both parties and leaders use comparative attacks more $(63.04 \%)$ than simple attacks $(36.96 \%)$. This means that when they attack their opponents and other agents, they also emphasize their achievements or positive aspects about themselves. In other words, they propose a destructive-constructive strategy combining criticism to attack their opponents with a proposal to incorporate and emphasize their ideas. This strategy is observed in the profiles of C's (87.5\%) and PSOE (77.27\%), on the one hand, and of Rivera (100\%), Sánchez (88.89\%), and Iglesias (85.71\%), on the other (Table 4). These opposition leaders use this strategy to emphasize errors and unfulfilled commitments of the Popular Party, as a party in the Government. At the same time, they position themselves as a political alternative to the Government. In contrast, there are messages whose argument is exclusively based on the attack (simple attack). These messages highlight the negative characteristics of the image, trajectory, or political management of rivals and other actors. This strategy is used mainly by Izquierda Unida $(66.67 \%)$ and its leader, Alberto Garzón (76.92\%).

Finally, the third strategy focuses on how political actors build the basis for their criticism. In general, both parties and leaders articulate the use of attacks based on emotions $(44.93 \%)$ (Table 4). These are messages that include expressions, images, or other resources used to evoke feelings and emotions. It mainly deals with negative emotions such as fear, disappointment, or anger. In this sense, they use the strength and impact of these emotions as a way to attract users, more likely to focus their attention when there is a negative context, as indicated by previous research (García Beaudoux and D'Adamo 2013).

However, there are some exceptions to this dynamic. On the one hand, parties such as the PSOE (45.45\%), or candidates such as Alberto Garzón (46.15\%), support most of their publications on criticisms of an ethical nature (Table 4). In this sense, they focus on negatively evaluating the lack of integrity, honesty, or trust of a particular political party, leader, proposal, or action. As political actors of the opposition, they focus on the Popular Party and Mariano Rajoy. 
On the other hand, criticism based on data or information has a lower level of use than the previous typologies $(21.01 \%)$. Crucial in its employment is the ideology of political actors. The use of C's (37.5\%) stands out as the party that most discredits its rivals, referring to empirical data, information, or statements they have previously made (Table 4). Using this type of strategy, they try to reinforce their attacks with the credibility and legitimacy that the data provides.

Table 4. How Political Actors Spread Criticism on Facebook (\%).

\begin{tabular}{|c|c|c|c|c|c|c|c|c|c|c|c|}
\hline & PP & PSOE & Podemo & s IU & $C^{\prime} s$ & Rajoy & Sánchez & Iglesias & Garzón & Rivera & TOTAL \\
\hline \multicolumn{12}{|c|}{ Intensity } \\
\hline Direct & 14.29 & 22.73 & 72.73 & 37.04 & 25 & - & 50 & 28.57 & 61.54 & 66.67 & 37.68 \\
\hline Collateral & 85.71 & 77.27 & 27.27 & 62.96 & 75 & - & 50 & 71.43 & 38.46 & 33.33 & 62.32 \\
\hline \multicolumn{12}{|c|}{ Structure of the attack } \\
\hline Simple & 57.14 & 22.73 & 45.45 & 66.67 & 12.5 & - & 11.11 & 14.29 & 76.92 & - & 36.96 \\
\hline Comparative & 42.86 & 77.27 & 54.55 & 33.33 & 87.5 & - & 88.89 & 85.71 & 23.08 & 100 & 63.04 \\
\hline \multicolumn{12}{|c|}{ Reason of the attack } \\
\hline Based on data & 14.29 & 22.73 & 27.27 & 22.22 & 37.5 & - & 11.11 & 28.57 & 15.38 & - & 21.01 \\
\hline Emotional & 85.71 & 27.27 & 54.55 & 55.56 & 25 & - & 44.44 & 71.43 & 38.46 & 100 & 44.93 \\
\hline Ethical & - & 45.45 & 18.18 & 3.7 & 37.5 & - & 33.33 & - & 46.15 & - & 27.54 \\
\hline Humorous & - & 4.55 & - & 18.52 & - & - & 11.11 & - & - & - & 6.52 \\
\hline
\end{tabular}

Finally, a petty but incipient use of humor is observed in the criticisms of political actors on Facebook. This formula is detected in the accounts of IU (18.52\%), Sánchez $(11.11 \%)$, and PSOE (4.55\%), who use it to ridicule their political opponents, though in a low percentage (Table 4). In this sense, political actors are beginning to moderately incorporate humor into their communication strategy and, in particular, in using criticism to attract more attention from users.

\subsection{The Reaction of Users on Facebook to the Criticism Issued by Political Actors}

It is relevant to delve into the reaction that this resource has generated in users present on Facebook. Thus, to answer RQ3, all the parameters that promote interaction on Facebook have been studied. That is, the comments, shares, and all different reactions that this social media allows: like, love, surprise (wow), laugh (haha), sad, and angry.

The results show three significant dynamics regarding users' reactions. First, messages including specific types of criticism obtain the highest number of comments and shares. As shown in Table 5, the publications that use this device have generated an average of 601.16 comments and 2681.64 shares, compared to the 571.60 comments and the 1980.91 shares of the messages excluding any sort of attack. This outcome indicates that users are more likely to incorporate comments and share those posts where criticism prevails. This dynamic may be the result of two factors. On the one hand, users support criticism with their comments while taking advantage of it to show their disagreement or dissatisfaction with the issue discussed. On the other, users extend criticism by sharing messages launched by political actors and assume them as their own.

Second, it has been detected that the posts without criticism obtain a higher average of positive or neutral reactions (Table 5). That is, messages where programmatic proposals are shared, an achievement or a personal aspect of political leaders is praised, among others, are valued with a higher number of Like, Love, Surprise, or Laugh. In this context, however, it should be considered that users do not always intend to show their support since reactions such as surprise or laughter are sometimes carried out to show irony in front of a message. 
Table 5. Average Interaction According to Whether the Messages of the Political Actors Contain Criticism.

\begin{tabular}{ccccccccccc}
\hline Critics & Commentaries & Shares & Like & Love & Surprise & Laugh & Sad & Angry & Total Reactions \\
\hline Yes & 601.16 & 2681.64 & 3653.67 & 334.38 & 6.77 & 56.10 & 33.40 & 74.81 & 4159.14 \\
No & 571.60 & 1980.91 & 3762.10 & 447.41 & 7.86 & 58.80 & 18.46 & 26.42 & 4321.05 \\
\hline
\end{tabular}

Finally, the results also suggest that the messages containing criticism receive the most negative reactions on average. Thus, users show intense sadness or anger when the publications shared by the analyzed political actors emphasize negative aspects (Table 5). The samples of anger are particularly noteworthy (74.81) and are higher when the critical messages are published by the parties and leaders.

\section{Conclusions and Discussion}

The results contain several original contributions that are applicable beyond Spain and reveal significant dynamics which enable us to broaden our knowledge about two components: first, the role of criticism in the communication strategy of political actors on Facebook during the electoral period; and second, how users of this social media react to this type of communication device. Specifically, five contributions stand out.

First, the results prove the presence of criticism as part of the communication strategy of political actors on Facebook. As observed in the case of different users in the digital environment such as citizens (Marcos-García et al. 2017), political parties, and leaders, all these take advantage of the disintermediation and openness offered by platforms like Facebook to start introducing criticism and attack into their discourse in the digital context. They use these messages to express their dissatisfaction and disagreement with certain proposals or actors (Jungherr 2016; Dang-Xuan et al. 2013). Criticism is an emerging device in the communication strategy of political actors (RQ1). They regard Facebook as a vehicle to self-promote their figure while condemning adversaries, criticizing the defects, errors, and contradictions that they may have committed (D'Adamo and Beaudox 2016; Ceron and d'Adda 2016; Valera-Ordaz and López-García 2014). However, as the previous literature has shown, this dynamic does not appear as a consequence of the impact of the Internet and social media but was already present in the offline electoral campaigns (Mazzoleni 2010). By introducing criticism in their messages on social media, parties and leaders exploit the characteristics of these platforms to introduce intrinsic dynamics of the political sphere (Stromer-Galley 2014; Valera-Ordaz and López-García 2014; Schweitzer 2010; Greer and LaPointe 2004; Klotz 2004).

Concerning this idea, the use of criticism by political actors on Facebook focuses on discrediting the image of their political rivals (RQ1). On the contrary, other actors linked to politics, such as the media or public institutions, receive little criticism. This use of criticism to attack political leaders is conditioned by two important parameters: ideology and position on the government-opposition axis. On the one hand, the ideological factor is decisive in the use of criticism on Facebook. In particular, left parties employ the attack the most in their digital communication strategies. On the contrary, right-wing parties make less use of this device on Facebook. On the other hand, the position on the government-opposition axis of both the formations and their respective candidates closely influences how they use criticism on Facebook. Thus, while the opposition political actors introduce a large number of attacks in their messages, both the party and the government leader barely employ this device. This idea is in line with what has been pointed out in the previous literature, which indicates that parties and leaders ideologically situated at the extremes criticize the moderate ones with greater frequency and intensity (Nai and Sciarini 2018; Lau and Pomper 2004). In this case, formations such as Izquierda Unida or leaders such as Pablo Iglesias and Alberto Garzón, all located in the opposition and with a left-wing ideology, are the most critical of the Popular Party, a formation in the Government, belonging to the right-wing moderate. 
Our second contribution is related to the type of criticism employed by political actors on Facebook (RQ2). In this case, the collective-individual axis is decisive, since the results show differences between the strategy proposed by the parties and the leaders. The parties emphasize the attack on the profile, focusing on the functions or positions held by opponents. Furthermore, they focus on political attacks, focusing on the electoral program of rivals. In other words, they focus their criticism on the professional role of their opponents. In contrast, leaders, and representatives of emerging parties, prioritize ideological attacks, targeting the beliefs and values of their political rivals. Thus, new parties try to differentiate themselves from the consolidated formations by suggesting proposals based on democratic regeneration and political change. This dynamic displays what has been pointed out by Valli and Nai (2020), who suggest that recently appearing parties, having a much shorter trajectory than traditional parties, tend to differentiate themselves from their opponents by highlighting their errors or defects rather than highlighting their achievements which are inexistent due to their recent emergence on the political scene. Regarding the personal attack centered on the attributes or personality traits or image of political rivals, although being in a developing state, it has also been used by the analyzed political actors. Thus, coinciding with the previous literature, parties and leaders find on social media such as Facebook a channel to criticize mainly the program, ideology, or trajectory of the opponent, but also other characteristics of the character or personality of rivals (Maier and Nai 2021; Stevens 2012; Lau and Pomper 2004).

The results reveal a fourth important finding concerning how political actors use criticism in their messages on Facebook (RQ2). Both political parties and leaders articulate criticism in their communication strategy around the use of emotions. To attract users' attention, political actors criticize their opponents by appealing to emotions. These data correspond to the findings of Abejón-Mendoza and Mayoral-Sánchez (2017) that confirm that in the 2016 Spanish general elections, the use of Facebook by the candidates was oriented towards fear and enthusiasm. Specifically, the traditional parties enhanced the emotion of fear, and the emerging parties focused their messages on creating illusion and enthusiasm for political change. This dynamic is directly related to the last of the findings, which shows that users react differently when messages contain attacks and when they do not (RQ3).

Coinciding with what was pointed out by previous literature, users increase their interaction when the posts issued by political actors include some type of criticism (Ballesteros-Herencia and Gómez-García 2020; Marcos-García et al. 2020), especially by sharing or commenting on those messages. At the same time, users use Facebook's tools to show anger and sadness in the publications where this resource appears. Therefore, we have demonstrated that negative emotions attract greater attention from users, who are prone to react to messages containing these types of emotions (García Beaudoux and D'Adamo 2013; Castells 2012). In this sense, it is observed how social media such as Facebook have become a space where users can actively participate in the political debate and show their support or dissatisfaction with the discourse shared by political actors (Marcos-García et al. 2017). This is a dynamic that can be problematic because it could increase the political disaffection of citizens and become a threat to democracy (Patterson 1993).

The results of this research show that criticism on Facebook is a complex device that goes beyond the simple attack on a political rival. Parties and leaders use it in the field of digital political communication, depending on several factors such as ideology, trajectory, or position on the government-opposition axis. This way, criticism is positioned as a strategic tool in electoral communication posed by political actors on social media. In this sense, it would be interesting to continue advancing in the study of criticism on social media to analyze if the use of this resource has increased or strengthened with the appearance of new far right political parties both at the national and international context. 


\begin{abstract}
Author Contributions: Conceptualization, S.M.-G., L.A.-M. and A.C.-R.; Methodology, S.M.-G. and L.A.-M.; Resources, S.M.-G. and L.A.-M.; Software, L.A.-M.; Validation, A.C.-R.; Formal Analysis, S.M.-G. and L.A.-M.; Investigation, S.M.-G. and L.A.-M.; Data Curation, S.M.-G. and L.A.-M.; Writing-Original Draft Preparation, S.M.-G. and L.A.-M.; Writing-Review \& Editing, S.M.-G., L.A.-M. and A.C.-R.; Visualization, S.M.-G.; Supervision, A.C.-R.; Project Administration, A.C.-R.; Funding Acquisition, A.C.-R. All authors have read and agreed to the published version of the manuscript.
\end{abstract}

Funding: This research is part of the research project CSO2017-88620-P, funded by the Spanish Research Agency (AEI) of the Government of Spain within the National Plan for R+D.

Conflicts of Interest: The authors declare no conflict of interest.

\title{
References
}

Abejón-Mendoza, Paloma, and Javier Mayoral-Sánchez. 2017. Persuasión a través de Facebook de los candidatos en las elecciones generales de 2016 en España. Profesional de la Información 26: 928-36. [CrossRef]

Alonso-Muñoz, Laura, Susana Miquel-Segarra, and Nadia Viounnikoff-Benet. 2021. The construction of the political agenda on Twitter and Facebook during the 2016 Spanish elections: Issues, frame and users' interest. The Journal of International Communication 27: 215-36. [CrossRef]

Alonso-Muñoz, Laura, and Andreu Casero-Ripollés. 2018. Communication of European populist leaders on Twitter: Agenda setting and the 'more is less' effect". El Profesional de la Información 27: 1193-202. [CrossRef]

Alonso-Muñoz, Laura, and Andreu Casero-Ripollés. 2017. Transparency and political monitoring in the digital environment. Towards a typology of citizen-driven platforms. Revista Latina de Comunicación Social 72: 1351-66.

Ballesteros-Herencia, Carlos A., and Salvador Gómez-García. 2020. Batalla de encuadres durante la campaña electoral de abril de 2019: Participación y promoción de los mensajes de los partidos políticos en Facebook. Profesional de la Información 29: e290629. [CrossRef]

Barberà, Òscar, Astrid Barrio, and Juan Rodríguez-Teruel. 2019. New parties' linkages with external groups and civil society in Spain: A preliminary assessment. Mediterranean Politics 24: 646-64. [CrossRef]

Benkler, Yochai. 2007. The Wealth of Networks. How Social Production Transforms Markets and Freedom. New Haven: Yale University Press.

Bennett, W. Lance. 2012. The personalization of politics: Political identity, social media, and changing patterns of participation. The ANNALS of the American Academy of Political and Social Science 644: 20-39. [CrossRef]

Berganza-Conde, María Rosa. 2008. Medios de comunicación, “espiral del cinismo" y desconfianza política. Estudio de caso de la cobertura mediática de los comicios electorales europeos. ZER-Revista de Estudios de Comunicación 13: 121-39.

Cabo Isasi, Álex, and Anna García Juanatey. 2016. El discurso del odio en las redes sociales: Un estado de la cuestión. Barcelona: Ajuntament de Barcelona. Available online: http:/ / ajuntament.barcelona.cat/bcnvsodi/wp-content/uploads/2017/02/Informe_discursodel-odio_ES.pdf (accessed on 15 April 2021).

Cammaerts, Bart, Alice Mattoni, and Patrick Mccurdy. 2013. Mediation and Protest Movements. Chicago: Intellect Books.

Castells, Manuel. 2012. Networks of Outrage and Hope. Social Movements in the Internet Age. Cambridge: Polity Press.

Castells, Manuel. 2009. Comunicación y poder. Madrid: Alianza.

Ceron, Andrea, and Giovanna d'Adda. 2016. E-campaigning on Twitter: The effectiveness of distribute promises and negative campaign in the 2013 Italian election. New Media E Society 18: 1935-55.

Chaves-Montero, Alfonso, Walter Federico Gadea-Aiello, and José Ignacio Aguaded-Gómez. 2017. La comunicación política en las redes sociales durante la campaña electoral de 2015 en España: Uso, efectividad y alcance. Perspectivas de la Comunicación 10: 55-83.

Coromina, Òscar, Emili Prado, and Adrián Padilla. 2018. The grammatization of emotions on Facebook in the elections to the Parliament of Catalonia 2017. Profesional de la Informacion 27: 1004-12. [CrossRef]

D’Adamo, Orlando, and Virginia García Beaudox. 2016. Comunicación Política: Narración de historias, construcción de relatos políticos y persuasión. Comunicación y Hombre 12: 23-39. [CrossRef]

Dahlberg, Lincoln. 2007. The Internet, deliberative democracy, and power: Radicalizing the public sphere. International Journal of Media $\mathcal{E}$ Cultural Politics 3: 47-64.

Dang-Xuan, Lihn, Stefan Stieglitz, Jennifer Wladarsch, and Christoph Neuberger. 2013. An investigation of influentials and the role of sentiment in political communication on Twitter during election periods. Information, Communication E Society 16: 795-825.

Digital Report. 2021. Digital Report 2021: El informe sobre las tendencias digitales, redes sociales y mobile. We are Social and Hootsuite. Available online: https:/ / wearesocial.com/digital-2021 (accessed on 30 March 2021).

Elmer, Greg. 2013. Live research: Twittering an election debate. New Media and Society 15: 18-30. [CrossRef]

Enli, Gunn. 2017. Twitter as arena for the authentic outsider: Exploring the social media campaigns of Trump and Clinton in the 2016 US presidential election. European Journal of Communication 32: 50-61. [CrossRef] 
Fenoll, Vicente, and Lorena Cano-Orón. 2017. Citizen Engagement on Spanish Political Parties Facebook Pages: Analysis of the 2015 Electoral Campaign Comments. Communication $\mathcal{E}$ Society 30: 131-48.

García Beaudoux, Virginia. 2014. El papel de las emociones en la comunicación política actual. Storytelling y estrategia de campaña negativa. Andamios 11: 39-48.

García Beaudoux, Virginia, and Orlando D’Adamo. 2013. Propuesta de una matriz de codificación para el análisis de las campañas negativas. Revista Opera 13: 7-23.

Geer, John G. 2006. In Defense of Negativity. Attack Ads in Presidential Campaigns. Chicago: The University of Chicago Press.

Greer, Jennifer, and Mark LaPointe. 2004. Cyber-Campaigning Grows Up. A Comparative Content Analysis of Websites for US Senate and Gubernatorial Races, 1998-2000. In Electronic Democracy: Mobilisation, Organisation and Participation via new ICTs. Edited by Rachel Gibson, Andrea Römmele and Steven Ward. London: Routledge, pp. 132-48.

Haro-de-Rosario, Arturo, Alejandro Sáez-Martin, and María del Carmen Caba-Pérez. 2016. Using Social to Enhance Citizen Engagement with Local Government: Twitter or Facebook? New Media \& Society 20: 29-49.

Jungherr, Andreas. 2016. Twitter use in election campaigns: A systematic literature review. Journal of Information Technology E Politics 13: 72-91.

Klotz, Robert. 2004. The Politics of Internet Communication. Lanham: Rowman \& Littlefield.

Lau, Richard R., and Gerald M. Pomper. 2004. Negative Campaigning: An Analysis of US Senate Elections. Lanham: Rowman \& Littlefield.

López-Meri, Amparo, Silvia Marcos-García, and Andreu Casero-Ripollés. 2017. What do politicians do on Twitter? Functions and communication strategies in the Spanish electoral campaign of 2016. Profesional de la Información 26: 795-804. [CrossRef]

López-Meri, Amparo, Silvia Marcos-García, and Andreu Casero-Ripollés. 2020. Communicative strategies on Facebook: Personalisation and community building in the 2016 elections in Spain. Doxa Comunicación 30: 229-48. [CrossRef]

Maarek, Philippe J. 2009. Marketing Político y Comunicación. Barcelona: Paidós.

Maier, Jürge, and Alessandro Nai. 2021. Mapping the drivers of negative campaigning: Insights from a candidate survey. International Political Science Review, 1-17.

Mann, Robert. 2011. Daisy Petals and Mushroom Clouds. LBJ, Barry Goldwater, and the Ad That Changed American Politics. Louisiana: LSU Press.

Marcos-García, Silvia, Laura Alonso-Muñoz, and Andreu Casero-Ripollés. 2017. Usos ciudadanos de Twitter en eventos políticos relevantes. La \#SesiónDeInvestidura de Pedro Sánchez. Comunicación y Hombre 13: 25-49.

Marcos-García, Silvia, Nadia Viounnikoff-Benet, and Andreu Casero-Ripollés. 2020. What is There in a 'Like'?: Political Content in Facebook and Instagram in The 2019 Valencian Regional Election. Debats 5: 85-109. [CrossRef]

Mathieu, David. 2015. The continued relevance of reception analysis in the age of social media. Tripodos 36: 13-34.

Mazzoleni, Gianpietro. 2010. La Comunicación Politica. Madrid: Alianza.

Nai, Alessandro, and Pascal Sciarini. 2018. Why "Going Negative?" Strategic and situational determinants of personal attacks in Swiss direct democratic votes. Journal of Political Marketing 17: 382-417. [CrossRef]

Orriols, Lluís, and Guillermo Cordero. 2016. The breakdown of the Spanish two-party system: The upsurge of Podemos and Ciudadanos in the 2015 general election. South European Society and Politics 21: 469-92. [CrossRef]

Patterson, Thomas E. 1993. Out of Order. New York: Alfred A. Knopf.

Shirky, Clay. 2011. The political power of social media: Technology, the public sphere, and political change. Foreign Affairs 90: $28-41$.

Stromer-Galley, Jennifer. 2014. Presidential Campaigning in the Internet Age. Oxford: Oxford University Press.

Schweitzer, Eva. 2010. Global patterns of Virtual Mudslinging? The Use of Attacks on German Party Websites in State, National and European Parliamentary Elections. German Politics 19: 200-10. [CrossRef]

Stevens, Daniel. 2012. Tone versus information: Explaining the impact of negative political advertising. Journal of Political Marketing 11: 322-52. [CrossRef]

Twiplomacy. 2020. Twiplomacy Study 2020. Twiplomacy. Available online: https:/ twiplomacy.com/blog/twiplomacy-study-2020/ (accessed on 27 January 2021).

Valera-Ordaz, Lidia, and Guillermo López-García. 2014. Agenda y marcos en las webs de PP y PSOE en la cibercampaña de 2011. Revista Latina de Comunicación Social 69: 41-66.

Valli, Chiara, and Alessandro Nai. 2020. Attack politics from Albania to Zimbabwe: A large-scale comparative study on the drivers of negative campaigning. International Political Science Review, 1-17. [CrossRef]

Vergeer, Maurice, Liesbeth Hermans, and Steven Sams. 2013. Online social networks and microblogging in political campaigning: The exploration of a new campaign tool and a new campaign style. Party Politics 19: 477-501. [CrossRef]

Vogt, Stine, and Svein Magnussen. 2007. Long term memory for 400 pictures on a common theme. Experimental Psychology 54: $298-503$. [CrossRef] 